need for routine sexual health testing and for future studies to better understand which MSW sub-populations are most at-risk. Disclosure of interest statement The ACCESS Sexual Health Services Network is funded by the NSW Ministry of Health, Victorian Department of Health, Australian Capital Territory Department of Health, and the Northern Territory Department of Health.

\section{P14.26 ANALYSIS OF RISK FACTORS INCIDENCE OF SEXUALLY TRANSMITTED INFECTIONS IN THE WOMEN INDIRECT SEX WORKERS IN MATARAM CITY, INDONESIA. 2012}

IK Mulyawan, Tris Cahyoso. Distric Health Office of Mataram, Indonesia

\subsection{6/sextrans-2015-052270.538}

Background Sexually transmitted infections are a public health problem in all countries, including Indonesia. The estimated number of people exposed to a sexually transmitted infection that can be treated approximately more than 30 million cases annually. In Mataram City 2011, found as many as 896 new cases of sexually transmitted infections. Women indirect sex workers have an important role in the spread of sexually transmitted infections and HIV-AIDS cases increased.

Research methods Design study was a cross sectional with a total sample of 66 women indirect sex workers. Risk factor of STIs is age of first sex, ever having sex, the number of customers per day, use of condoms, clean hands after sex, change underwear after sex, alcohol consumption habits and the habit of consuming drugs. Potential risk factors were explored using a structured questionnaire of the month from May to June 2012. Data were analysed using, bivariable and multivariable statistics.

Results From the bivariable analysis, risk factors for STIs were ever having sex (OR 2.33, CI 5.15-1:05), not using condoms (OR 3.13, CI: 1.36 to 7.20) and the number of customers per day (OR 2.60, CI: 1.13 to 6.01). Multivariable analysis showed that the risk factors that influence the incidence of sexually transmitted infections are not using condoms (adjusted OR 6.55, CI 1.83 to 23,43 ) and the number of customers per day (adjusted OR 5.01, CI 1.41 to 18.29).

Conclusion Not using a condom in serving customers in women indirect sex workers be risk factors for STIs. Need an effort to monitor the prevalence of sexually transmitted infections continued cooperation and support of stakeholder in pressing the prevalence of STIs.

\section{P14.27 FEMALE SEX WORKERS (FSW) IN BA RIA - VUNG TAU, VIETNAM: SOCIO-DEMOGRAPHIC CHARACTERISTICS AND RISK BEHAVIOURS}

${ }^{1} \mathrm{~T}$ Nguyen, ${ }^{1} \mathrm{D}$ Stewart, ${ }^{2} \mathrm{MK}$ Bui, ${ }^{3} \mathrm{TNH}$ Dang. ${ }^{1}$ School of Medicine, Griffith University; ${ }^{2}$ HIVI AIDS Prevention Centre of Ba Ria - Vung Tau, Vietnam; ${ }^{3}$ Preventive Medicine Centre of Ba Ria - Vung Tau, Vietnam

\subsection{6/sextrans-2015-052270.539}

Background FSWs are a high-risk population group for the transmission and acquisition of STIs and HIV. This research investigated socio-demographic characteristics and risk behaviours among FSWs in Ba Ria - Vung Tau, Vietnam.

Methods Data were collected using a cross-sectional survey of 420 direct/indirectly employed FSWs between January-May, 2014, from 2 cities/6 districts in Ba Ria - Vung Tau. FSWs were interviewed using a structured questionnaire and biological samples taken and tested for STI/HIV. Data were entered (Epidata 3.1) and analysed (SPSS 20.0) using univariate and multivariate analyses to investigate the associations between STIs and riskrelated factors.

Results 166 direct and 254 indirect FSWs participated in the survey, with a median age of 27 years, within a range of 18-43 years. Many (43.3\%) had minimal education (grade 5 or less). Most claimed religious affiliation (90.5\%) and 91.7\% were of Kinh ethnicity. At $63.1 \%$, the unemployment rate before becoming FSWs was high. There were significant differences between direct/indirect types of FSWs in terms of: education levels (OR $=2.46,95 \% \mathrm{CI}: 1.65-3.67, \mathrm{p}=0.001)$; marital status, including married or cohabitating (OR $=2.14,95 \%$ CI: $1.43-3.207$, $\mathrm{p}=0.001)$; unemployment before becoming FSWs $(\mathrm{OR}=2.36$, 95\% CI: 1.54-3.63, $\mathrm{p}=0.001)$; low income $\leq \mathrm{A} \$ 200(\mathrm{OR}=$ 3.74 , 95\% CI: $1.83-7.65, \mathrm{p}=0.001)$; and number of paying clients in the last month $>15(\mathrm{OR}=24.88,95 \% \mathrm{CI}: 14.73-$ 42.01, $\mathrm{p}=0.001)$. Inconsistent condom use with regular and new clients was $21.8 \%$ and $15.2 \%$ respectively. Most (89.0\%) FSWs performed oral sex, also a high proportion $(82.4 \%)$ of them consumed alcohol. Nearly half (48.3\%) have had sex when drunk. Regarding drug use, 23.4\% FSWs have used drugs and 26.1\% have clients who use or inject drugs.

Conclusions FSWs in Vietnam need targeted intervention programs and improved services to prevent HIV and STIs infection. Administrative and political support for improved health education and services are required to prevent the epidemic from spreading.

\section{P14.28 SEXUAL TRANSMITTED INFECTIONS AND RISK FACTORS AMONG FEMALE SEX WORKERS IN BA RIA - VUNG TAU, VIETNAM}

${ }^{1} \mathrm{~T}$ Nguyen, ${ }^{1} \mathrm{D}$ Stewart, ${ }^{2} \mathrm{MK}$ Bui, ${ }^{3} \mathrm{TNH}$ Dang. ${ }^{1}$ School of Medicine, Griffith University; ${ }^{2} \mathrm{HIV} /$ AIDS Prevention Centre of Ba Ria - Vung Tau, Vietnam; ${ }^{3}$ Preventive Medicine Centre of Ba Ria - Vung Tau, Vietnam

\subsection{6/sextrans-2015-052270.540}

Introduction Sexually transmitted infections (STIs) continue to be a major concern in public health because of their high incidence and prevalence. STIs are also a major problem for FSWs in Vietnam. The purpose of the research is to determine the prevalence of STIs and risk-related factors in Ba Ria - Vung Tau, Vietnam.

Methods Data were collected using a cross-sectional survey of 420 direct and indirect FSWs between January-May, 2014, from 2 cities and 6 districts in Ba Ria - Vung Tau. FSWs were interviewed using a structured questionnaire and biological samples taken and tested for HIV. A database was created using Epidata 3.1 software and analysed using the SPSS 20.0 statistical package. Univariate and multivariate analyses were used to investigate the associations between STIs and risk-related factors.

Results Prevalence were $6.9 \%$ for Syphilis, 7.9\% for Gonorrhoea (GC), $16.4 \%$ for Chlamydia (CT) and $21.4 \%$ for any one of the STIs (GC/CT). Increased risks for GC/CT were associated with age of first sexual intercourse $\leq 18$ (OR 3.57, 95\% CI: $2.11-$ $6.06, \mathrm{p}=0.011)$; number of paying clients in the past month $>15(\mathrm{OR}=2.16,95 \% \mathrm{CI}: 1.34-3.46, \mathrm{p}=0.001)$; inconsistent condom use with regular customers $(\mathrm{OR}=1.98,95 \% \mathrm{CI}: 1.17-$ $3.37, \mathrm{p}=0.010)$ and new customers $(\mathrm{OR}=2.18,95 \% \mathrm{CI}$ : $1.20-3.94, \mathrm{p}=0.009)$; and unprotected sex with non-paying partners $(\mathrm{OR}=3.89,95 \% \mathrm{CI}: 1.51-10.00, \mathrm{p}=0.003) . \mathrm{A}$ 
higher likelihood of Syphilis was significantly associated with having anal sex $(\mathrm{OR}=3.14,95 \% \mathrm{CI}: 1.25-7.85, \mathrm{p}=0.010)$.

Conclusion The prevalence of STIs is high among FSWs in $\mathrm{Ba}$ Ria-Vung Tau, Vietnam. Therefore, the existing STIs treatment and intervention programs should be reviewed and if necessary modified or strengthened to reduce the risk of infection. Health education, especially relevant to the risk-related factors observed in the study should be improved and $100 \%$ condom use program should be implemented.

\section{P14.29 ESTABLISHMENT OF HEALTH RESEARCH ETHICS AND CAPACITY BUILDING OF HUMAN RESOURCES AND INFRASTRUCTURE IN NIGERIA}

${ }^{1} \mathrm{MN}$ Otuonye*, ${ }^{1} \mathrm{FO}$ Nwaokorie, ${ }^{2} \mathrm{D}$ Suprumont, ${ }^{3} \mathrm{~T}$ Halidou, ${ }^{4}$ Morenike Ukpong. ${ }^{1}$ Nigerian Institute of Medical Research, Yaba, Lagos, Nigeria; ${ }^{2}$ Institute de Droit de La Sante, Faculty de Droit Neuchatel Switzerland; ${ }^{3}$ RSS-DRO/Centre Muraz 01, Bobo Dioulass Burkina Faso; ${ }^{4}$ University of Ife Osun State Nigeria

\subsection{6/sextrans-2015-052270.541}

Background The purpose of this project was to train Health Personnel and Biomedical researchers to design protocols with ethical integrity and to approve the conduct of protocols with scientific merit.

Methodology Forty eight (48) biomedical researchers comprising of biomedical researchers and health professionals, legal officers, clergy, community representative were trained on Human subject protection and ethical review of research protocols. This comprises of Basic principles and international guidelines on bioethics, Basics of Research and Clinical Trials, Ethical review of research protocols. Other slides that were presented included: Standard of care and prevention, research protocol, GPP, GCP, Informed consent, HIV treatment, monitoring of research conduct etc. The training modules used for this training was approved by the National Health Research Ethics Committee according to the International Ethical Guidelines for Biomedical Research Involving human subjects. A Pre and Post-test was used to evaluate participants' performance. The HREC office infrastructure was strengthened and they are now registering with NHREC. Stata 12 statistical software was used for data analysis. Results The pre- and post-test evaluation indicated that participants' knowledge improved significantly in conduct of ethically sound research $(30.3 \%$ vs $65.0 \%, \mathrm{p}=0.001)$. A 15 membership HREC was constituted by the NHREC and officially handed over to the management of Ambrose Alli Uiversity.

Conclusion Training of biomedical researchers, increased their knowledge and skill in reviewing research protocols, and conduct research that is ethically regulated and of international standard. This would maintain public confidence that individuals' autonomy would be respected.

\section{P15 - HIV basic sciences}

\section{P15.01 INNATE MUCOSAL SERPIN INHIBITS LATE STAGES OF HIV LIFE CYCLE AND REDUCES CELLULAR PROLIFERATION}

1,2 L Aboud*, ${ }^{2} \mathrm{KD}$ Jayappa, ${ }^{1,3} \mathrm{~B}$ Abrenica, ${ }^{4} \mathrm{~J}$ Kimani, 2,3 $\mathrm{F}$ Plummer, ${ }^{1,2,3} \mathrm{~A}$ Burgener, 1,2,5,3 TB Ball. 'J. C Wilt Infectious Disease Research Centre, Winnipeg, Manitoba; ${ }^{2}$ Department of Medical Microbiology; ${ }^{3}$ Winnipeg, Canada, National HIV and Retrovirology Laboratory, Public Health Agency of Canada, Canada; ${ }^{4}$ Department of Medical Microbiology, University of Nairobi, Kenya; ${ }^{5}$ mmunology, University of Manitoba

\subsection{6/sextrans-2015-052270.542}

Background Antiproteases, specifically serpins, are up-regulated within cervicovaginal fluid (CVF), of highly-exposed sero-negative women (HESN), within the Pumwani cohort in Nairobi, Kenya. These proteins are presumed to contribute to the overall susceptibility of a woman to HIV-1. We hypothesise that CVF from HESN women will exhibit stronger HIV neutralisation activity, compared to HIV susceptible women. We believe that overabundant serpins within CVF are capable of neutralising HIV infection and will do so through both direct and indirect anti-HIV mechanisms and are potential novel microbicide candidates.

Methodology HIV-1 neutralisation assays were performed with individual CVL samples from HESN and HIV-susceptible women. Real time-PCR was utilised to determine the level of viral DNA as well as viral mRNA following treatment with the serpin of interest. ACH2 cells, determined the effect of the antiprotease on late stages of the viral life cycle and confocal microscopy revealed levels of cellular entry and specific localization of the exogenously added serpin. Lastly, flow cytometry was employed to determine the effect of the protein on cellular proliferation.

Results No significant difference was observed in the neutralisation capacity of CVF between HESN and HIV-susceptible women. However, various serpins within the CVF, when isolated and added exogenously to cell cultures, did exhibit significant HIV-neutralising effects. Following numerous mechanistic studies on one such serpin, it was apparent that it not only interferes with proper cellular proliferation but also directly in late stages of the virus lifecycle, (post-transcriptionally) likely during translation or assembly/budding of the virion.

Conclusion Cervical vaginal fluid contains a myriad of immunomodulatory proteins that may contribute to a woman's overall susceptibility to HIV infection. The serpin studied within this project demonstrates both broad (cellular proliferation) and narrow (HIV specific) mechanisms of action, making it a potentially effective microbicide candidate.

Disclosure of interest statement Nothing to declare. 